\title{
Peningkatan Keaktifan dan Hasil Belajar Materi Lingkaran Melalui Course Review Horay Kelas VIIIA SMP 4 Bae Tahun 2020
}

\author{
Siti Malikhah \\ SMP 4 Bae Kudus \\ sitimalikhah.4bae@gmail.com
}

\begin{abstract}
ABSTRAK
Penelitian ini bertujuan untuk meningkatkan keaktifan dan hasil belajar Lingkaran melalui Course Review Horay $(C R H)$ bagi peserta didik kelas VIIIA SMP 4 Bae semester 2 tahun 2020. Penelitian dilaksanakan selama 2 bulan mulai bulan Januari hingga Februari 2020. Subjek penelitian ini adalah peserta didik kelas VIIIA SMP 4 Bae semester 2 tahun 2020. Sumber data diambil dari peserta didik berupa pengamatan langsung oleh observer dan hasil penilaian harian. Untuk menganalisis data, peneliti menggunakan lembar observer dan deskripsi komparatif. Metode yang digunakan meliputi empat tahapan yakni perencanaan, pelaksanaan, pengamatan dan refleksi. Tiap siklus terdiri dari 2 pertemuan. Hasil penelitian menunjukkan bahwa melalui model pembelajaran $C R H$ dapat meningkatkan keaktifan dan hasil belajar Lingkaran bagi peserta didik kelas VIIIA SMP 4 Bae semester 2 tahun 2020.
\end{abstract}

Kata kunci: $C R H$, keaktifan dan hasil belajar, lingkaran.

\section{ABSTRACT}

This Research aims to increase the activity and learning outcomes of the Circle through Course Review Horay (CRH) for class VIIIA students of SMP 4 Bae semester 2 of 2020. The research was carried out for 2 months from January to February 2020. The research subjects these are class VIIIA students of SMP 4 Bae semester 2 in 2020. The data sources are taken from students in the form of direct observations by observers and the results of daily assessments. To analyze the data, the researcher used observer sheets and comparative descriptions. The method used is research which includes four stages, namely planning, implementation, observation and reflection. Each cycle consists of 2 meetings. The results showed that the CRH learning model could increase the activity and learning outcomes of the Circle for class VIIIA students of SMP 4 Bae semester 2 of 2020.

Keywords: CRH, activity and learning outcomes, circle. 


\section{PENDAHULUAN}

Berdasarkan hasil penilaian akhir semester 1 peserta didik kelas VIIIA didapatkan ratarata nilai mata pelajaran matematika sebesar 63 dengan KKM yakni 68. Dari 30 peserta didik hanya 11 peserta didik yang memenuhi KKM, sedangkan 19 peserta didik lainnya masih di bawah KKM. Rata-rata nilai di kelas VIIIA yang rendah dapat dipengaruhi oleh beberapa faktor di antaranya peneliti masih menggunakan metode mengajar secara konvensional dimana pembelajaran masih berpusat pada peneliti. Peneliti lebih banyak memberikan ceramah sedangkan peserta didik hanya bersikap pasif mendengarkan. Akibatnya keaktifan dan hasil belajar peserta didik di kelas VIIIA masih rendah.

Keaktifan merupakan kegiatan bersifat fisik maupun mental, yaitu berbuat dan berfikir sebagai suatu rangkaian yang tidak dapat dipisahkan (Sadirman dalam Ingti Binova A, 2017:10). Sedangkan hasil belajar menurut Maslikhan (2015:15) merupakan patokan yang menentukan tingkat keberhasilan peserta didik dalam mengetahui dan memahami suatu materi pelajaran dari proses pengalaman belajarnya yang diukur dengan tes. Lebih lanjut, Dimyati \& Mudjiono (dalam Anisak Nur Falah, 2018:18-19) menyatakan bahwa keaktifan belajar peserta didik dipengaruhi oleh faktor intern yang ada pada diri peserta didik itu sendiri dan guru yang merupakan faktor ekstern. Faktor intern terdiri dari sikap, motivasi, konsentrasi, mengolah, menyimpan, menggali, dan unjuk berprestasi. Sedangkan faktor ekstern terdiri dari pengorganisasian belajar, bahan belajar dan sumber belajar, serta evaluasi belajar.

Berdasarkan fakta tersebut di atas maka peneliti berharap agar keaktifan dan hasil belajar Lingkaran peserta didik kelas VIIIA SMP 4 Bae semester 2 tahun 2020 dapat meningkat dengan penggunaan model pembelajaran Course Review Horay $(\mathrm{CRH})$. Keaktifan belajar peserta didik perlu ditingkatkan agar komunikasi antara guru dan peserta didik serta peserta didik dengan peserta didik semakin meningkat. Dengan meningkatnya keaktifan belajar peserta didik diharapkan dapat meningkatkan pemahaman peserta didik terhadap konsep Lingkaran. Hasil penelitian Fahmi Royani et al., (2020) menyatakan bahwa terdapat pengaruh positif yang signifikan keaktifan peserta didik terhadap hasil belajar.

Permasalahan yang dihadapi peneliti berdasarkan latar belakang tersebut di atas adalah sebagai berikut. (1) Apakah keaktifan belajar lingkaran peserta didik kelas VIIIA SMP 4 Bae semester 2 tahun 2020 dapat ditingkatkan melalui model pembelajaran $C R H$ ? (2) Apakah hasil belajar Lingkaran peserta didik kelas VIIIA SMP 4 Bae semester 2 tahun 2020 dapat ditingkatkan melalui model pembelajaran $C R H$ ?

Oleh karena itu untuk memecahkan masalah tersebut maka harus ada tindakan yang dilakukan oleh peneliti yaitu penggunaan model pembelajaran $C R H$. Model pembelajaran $C R H$ merupakan gabungan dari kegiatan diskusi kelompok disertai persaingan antarkelompok yang menyenangkan. Ciri khas dari model pembelajaran $C R H$ adalah adanya yel-yel bagi kelompok yang menjawab soal dengan benar. Model pembelajaran $C R H$ diawali dengan penjelasan singkat oleh guru tentang materi yang harus dikuasai oleh peserta didik. Selanjutnya peserta didik membentuk kelompok heterogen yang terdiri dari putra dan putri dengan banyak anggota tiap kelompok adalah 5 orang. Untuk mengetahui sejauh mana pemahaman peserta didik terhadap konsep yang disampaikan oleh guru maka guru membuat kotak $3 \times 3$ di papan tulis. Selanjutnya perwakilan kelompok saling berebut untuk maju dan menulis jawaban pada kotak 
tersebut sesuai nomor soal. Setiap kelompok yang menjawab dengan benar diharuskan untuk bersorak atau menampilkan yel-yel.

CRH merupakan suatu model pembelajaran yang dapat menciptakan suasana kelas menjadi meriah dan menyenangkan karena setiap peserta didik yang dapat menjawab benar diwajibkan berteriak 'horeee' atau yel-yel lainnya yang disukai (Miftahul Huda, 2014:229230). Hal ini sesuai dengan Fitrah Amelia dan Ferdinand Herman Siahaan (2015). Model pembelajaran $C R H$ merupakan salah satu pembelajaran kooperatif, yaitu kegiatan belajar mengajar dengan cara pengelompokan peserta didik ke dalam kelompok-kelompok kecil. Model pembelajaran ini merupakan suatu pengujian terhadap pemahaman konsep peserta didik menggunakan kotak yang diisi dengan soal dan diberi nomor untuk menuliskan jawabannya. Kelompok yang paling terdahulu menjawab pertanyaan dengan benar langsung berteriak horay atau yel-yel lainnya. Melalui model pembelajaran $C R H$ diharapkan dapat melatih peserta didik menyelesaikan masalah dengan pembentukan kelompok kecil dan juga dapat meningkatkan keaktifan kelompok.

Kelebihan dari model pembelajaran CRH menurut Shoimin (2014:55) adalah (a) menarik sehingga mendorong peserta didik terlibat di dalamnya, (b) tidak monoton karena diselingi sedikit hiburan sehingga suasana tidak menegangkan, (c) peserta didik lebih bersemangat, dan (d) melatih kerja sama.

Langkah-langkah model pembelajaran $C R H$ dalam penelitian ini adalah sebagai berikut.

a. Guru menyampaikan kompetensi yang ingin dicapai.

b. Guru mendemonstrasikan/menyajikan materi.

c. Memberikan kesempatan kepada peserta didik untuk tanya jawab.

d. Guru membagi peserta didik dalam kelompok heterogen (masing-masing kelompok beranggotakan 5 peserta didik).

e. Untuk menguji pemahaman peserta didik, guru membuat kotak $3 \times 3$ dan diberi nomor 1-9.

f. Guru membaca soal secara acak (nomor soal 1-9).

g. Tiap kelompok berdiskusi dengan anggota kelompok untuk menentukan jawaban soal.

h. Perwakilan kelompok berebut menulis jawaban di dalam kotak yang nomornya disebutkan guru. Jika benar diberi tanda $\sqrt{ }$ dan salah diberi tanda $\mathrm{x}$.

i. Kelompok yang menjawab dengan benar harus berteriak horay atau yel-yel lainnya.

j. Kelompok yang berhasil mendapat tanda $\sqrt{ }$ vertikal, horizontal atau diagonal akan mendapatkan hadiah berupa ucapan selamat dari seluruh anggota kelompok lainnya dengan cara bersalaman satu persatu.

k. Penutup.

Untuk lebih meyakinkan lagi, penulis melakukan studi pustaka terhadap hasil penelitian yang berkaitan dengan model pembelajaran $C R H$ serta pengaruh keaktifan belajar terhadap hasil belajar peserta didik. Yang pertama adalah "Pengaruh Gaya Belajar dan Keaktifan Siswa Terhadap Prestasi Belajar Matematika (Survei Pada SMP Negeri di Kecamatan Klari Kabupaten Karawang)" merupakan judul penelitian dari Ramlah et al., (2014). Hasil penelitian tersebut menyatakan bahwa terdapat pengaruh yang signifikan keaktifan terhadap prestasi belajar matematika, hal ini dapat dilihat dari nilai $\mathrm{F}$ hitung $=13,418>\mathrm{F}$ tabel $=3,08$, dengan $\operatorname{sig}=0,00<\alpha=0,05$.

Hasil penelitian dari Noor Laila Atini dan Ali Mahmudi (2016) dengan judul "Keefektifan Cooperative Learning CRH dan NHT Ditinjau dari Sikap dan Prestasi Belajar Matematika 
Siswa" menunjukkan bahwa model pembelajaran kooperatif tipe Course Review Horay $(\mathrm{CRH})$ lebih efektif dibanding model pembelajaran kooperatif tipe Numbered Heads Together (NHT) ditinjau dari sikap peserta didik terhadap matematika dan prestasi belajar matematika.

Asih Suryani et al., (2016) hasil penelitiannya yang berjudul "Pengaruh Pendekatan Course Review Horay (CRH) Terhadap Pemahaman Matematis dan Motivasi Belajar Matematika Siswa Sekolah Dasar Pada Materi Penjumlahan dan Pengurangan Bilangan Bulat" menunjukkan bahwa pembelajaran dengan pendekatan $C R H$ dapat meningkatkan pemahaman matematis peserta didik pada materi penjumlahan dan pengurangan bilangan bulat secara signifikan. Peningkatan tersebut ditunjukkan dari nilai rata-rata pre-tes dan post-tes yang mengalami kenaikan sebesar 39,63 dan memberikan kontribusi terhadap peningkatan pemahaman matematis peserta didik sebesar 37\%. Selain itu peningkatan pemahaman matematis peserta didik dengan pembelajaran $C R H$ pada materi penjumlahan dan pengurangan bilangan bulat lebih baik dibanding dengan pembelajaran konvensional, dibuktikan nilai ratarata gain pada kelas eksperimen lebih besar, yakni sebesar 0,691 dibanding kelas kontrol yang hanya sebesar 0,44. Demikian juga persentase kontribusi pendekatan pembelajaran menunjukkan bahwa pembelajaran $C R H$ 3\% lebih banyak memberikan kontribusi dibanding dengan pembelajaran konvensional.

\section{METODE PENELITIAN}

Penelitian ini dilakukan selama 2 bulan yaitu mulai bulan Januari hingga Februari 2020. Subjek penelitian ini adalah peserta didik kelas VIIIA SMP 4 Bae semester 2 tahun 2020 sebanyak 30 orang. Objek penelitian ini meliputi keaktifan dan hasil belajar Lingkaran peserta didik kelas VIIIA SMP 4 Bae semester 2 tahun 2020. Penelitian ini bersumber pada data yang dikumpulkan dari peserta didik yaitu hasil penilaian harian tiap siklus. Variabel yang akan diamati dalam penelitian ini adalah keaktifan belajar dan hasil belajar peserta didik.

Sumber data yang lainnya adalah dari teman sejawat sesama guru matematika. Peneliti bekerja sama dengan teman sejawat yang merupakan guru mata pelajaran matematika pengampu kelas VIII. Data yang dikumpulkan dari teman sejawat antara lain hasil observasi keaktifan peserta didik dalam setiap siklusnya. Bentuk data yang digunakan untuk keaktifan belajar peserta didik berupa data kualitatif. Sedangkan data untuk penilaian harian berupa data kuantitatif.

Analis data pada penelitian ini menggunakan analisis deskriptif kualitatif. Analisis deskriptif komparatif yang mencakup keaktifan belajar dan hasil belajar dilakukan dengan cara membandingkan keaktifan belajar pada Pra siklus, Siklus 1, dan Siklus 2.

Selanjutnya adalah menarik kesimpulan berdasarkan deskriptif komparatif dari keaktifan belajar dan hasil belajar peserta didik. Berdasarkan kesimpulan yang didapat maka peneliti membuat ulasan dan menentukan tindakan yang akan dilakukan berikutnya.

Penelitian tindakan kelas ini terdiri dari dua siklus yakni siklus 1 dan siklus 2 . Pada siklus 1 peneliti menerapkan model pembelajaran $C R H$ dengan langkah-langkah pada kegiatan inti adalah sebagai berikut. (1) Guru mendemonstrasikan/menyajikan materi, (2) guru memberikan kesempatan kepada peserta didik untuk tanya jawab, (3) guru membagi peserta didik dalam kelompok heterogen (masing-masing kelompok beranggotakan 5 peserta didik), (4) untuk menguji pemahaman, guru membuat kotak $3 \times 3$ yang berisi 9 kotak di papan tulis, (5) guru 
membaca soal secara acak dan tiap kelompok berebut menulis jawaban di dalam kotak yang nomornya disebutkan guru, jika benar diberi tanda $\sqrt{ }$ dan salah diberi tanda $X$, (6) kelompok yang menjawab dengan benar harus berteriak horay atau yel-yel lainnya, dan (7) kelompok yang berhasil mendapat tanda $\sqrt{ }$ vertikal, horizontal atau diagonal akan mendapatkan hadiah berupa ucapan selamat dari seluruh anggota kelompok lainnya dengan cara bersalaman satu persatu.

Siklus 2 akan dilaksanakan dengan langkah-langkah yang sama dengan siklus 1 . Perbedaannya adalah pada siklus 2 ini peneliti akan membentuk kelompok dengan anggota sebanyak 4 peserta didik.

Setelah peneliti melaksanakan siklus 1 dan siklus 2, diharapkan dapat meningkatkan keaktifan dan hasil belajar Lingkaran melalui Course Review Horay peserta didik kelas VIIIA SMP 4 Bae semester 2 tahun 2020. Kerangka berpikir dari penelitian ini dapat dilihat pada Gambar 1.

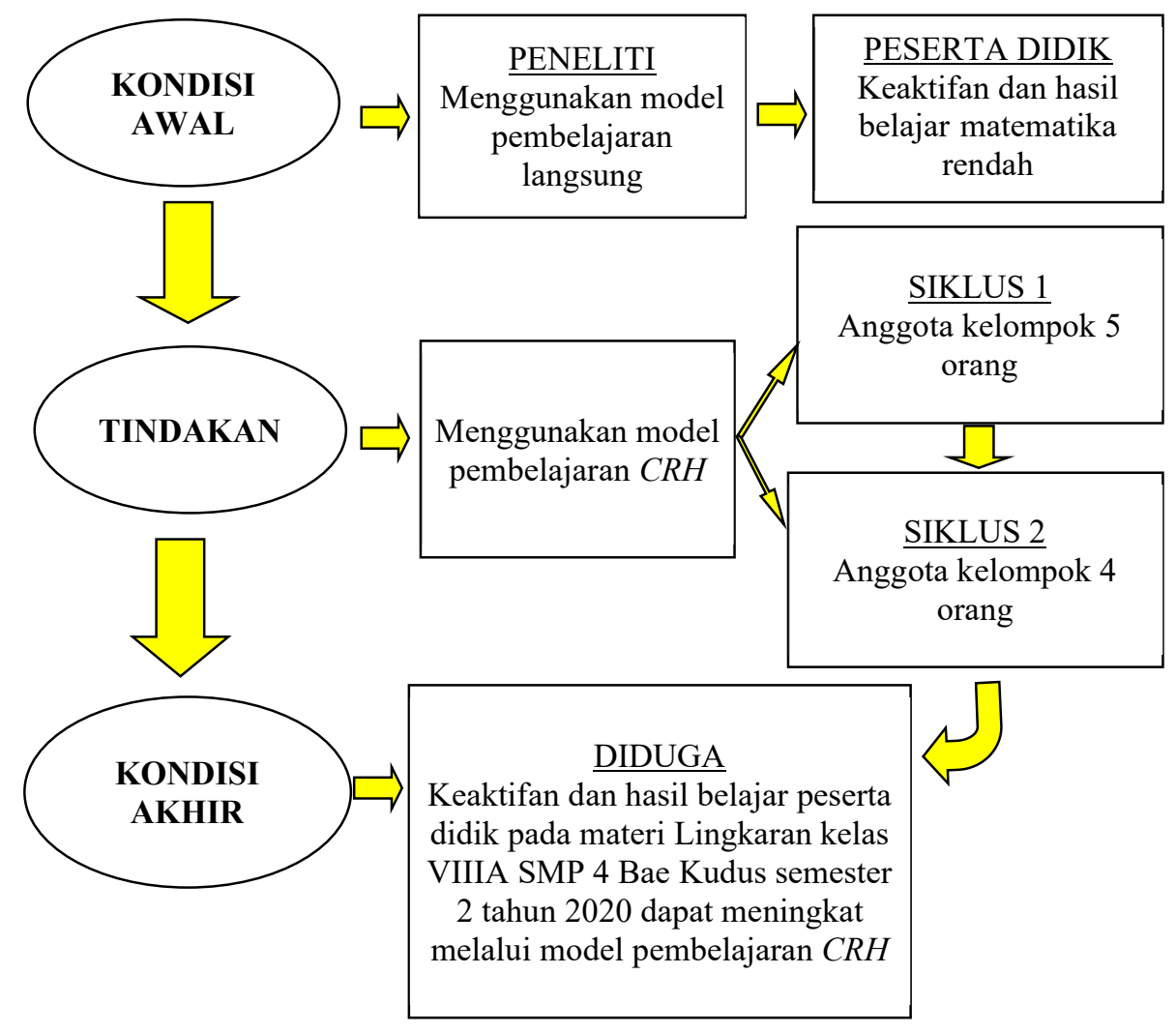

Gambar 1. Kerangka Berpikir Penelitian

\section{HASIL DAN PEMBAHASAN}

\subsection{Deskripsi Kondisi Awal}

Keaktifan belajar peserta didik kelas VIIIA pada semester 1 masih rendah. Sebagian peserta didik tidak menyimak penjelasan guru, tidak melaksanakan diskusi dengan baik, tidak mau menyampaikan pendapat, tidak mencatat dengan lengkap dan tidak bersemangat. Adapun keaktifan belajar dan hasil belajar peserta didik kelas VIIIA kondisi Prasiklus secara rinci dapat dicermati pada Tabel 1. 
Tabel 1. Keaktifan Belajar Prasiklus

\begin{tabular}{clcc}
\hline No & \multicolumn{1}{c}{ Aspek Pengamatan } & Jumlah & Persentase \\
\hline 1 & Menyimak penjelasan guru & 14 orang & $47 \%$ \\
2 & Melaksanakan diskusi kelompok sesuai petunjuk guru & 5 orang & $17 \%$ \\
3 & Menyampaikan pendapat kepada guru atau sesama peserta didik & 3 orang & $10 \%$ \\
4 & Menulis dengan lengkap & 13 orang & $43 \%$ \\
5 & Bergembira dan bersemangat & 10 orang & $33 \%$ \\
\hline
\end{tabular}

Tabel 2. Hasil Belajar Prasiklus

\begin{tabular}{clc}
\hline No. & \multicolumn{1}{c}{ Uraian } & Nilai \\
\hline 1. & Nilai terendah & 52 \\
2. & Nilai tertinggi & 89 \\
3. & Nilai rata-rata & 63 \\
4. & Persentase ketuntasan & $37 \%$ \\
\hline
\end{tabular}

Berdasarkan Tabel 1 dapat dinyatakan bahwa keaktifan peserta didik masih rendah. Dari 30 orang, 14 orang menyimak penjelasan guru dan 16 orang lainnya tidak menyimak. Kegiatan yang dilakukan peserta didik ketika tidak menyimak guru di antaranya adalah mengobrol dengan teman lainnya, mengantuk atau melamun. Untuk kegiatan diskusi hanya ada 5 orang yang melaksanakan diskusi kelompok sesuai petunjuk guru. Bahkan yang menyampaikan pendapat kepada guru atau sesama peserta didik sejumlah 3 orang saja. Sedangkan peserta didik lainnya bersikap pasif. 13 orang menulis dengan lengkap dan 10 orang yang bergembira dan bersemangat. Dalam kondisi keaktifan yang rendah maka kecil kemungkinan bagi peserta didik untuk mendapatkan hasil belajar yang mencapai KKM. Hal ini tergambarkan pada Tabel 2 dengan rata-rata nilai mata pelajaran matematika sebesar 63. Rata-rata nilai tersebut masih di bawah KKM yakni 68 .

\subsection{Deskripsi Hasil Siklus 1}

Pada tahap ini peneliti bersama observer mengamati proses pembelajaran dan mencatat hasil pengamatannya. Hasil pengamatan ditulis pada lembar observasi yang telah disiapkan oleh peneliti. Hasil pengamatan menyatakan bahwa proses pembelajaran telah sesuai dengan RPP yang telah dibuat oleh peneliti. Alokasi waktu yang disediakan telah dapat dilaksanakan dengan baik. Adapun ringkasan hasil dari keaktifan belajar dan hasil belajar pada Siklus 1 dirangkum dalam Tabel 3.

Tabel 3. Keaktifan Belajar Siklus 1

\begin{tabular}{clcc}
\hline No. & \multicolumn{1}{c}{ Aspek Pengamatan } & Jumlah & Persentase \\
\hline 1 & Menyimak penjelasan guru & 26 orang & $87 \%$ \\
2 & Melaksanakan diskusi kelompok sesuai petunjuk guru & 26 orang & $87 \%$ \\
3 & Menyampaikan pendapat kepada guru atau sesama peserta didik & 17 orang & $57 \%$ \\
4 & Menulis dengan lengkap & 27 orang & $90 \%$ \\
5 & Bergembira dan bersemangat & 26 orang & $87 \%$ \\
\hline
\end{tabular}

Tabel 4. Hasil Belajar Siklus 1

\begin{tabular}{llc}
\hline No. & \multicolumn{1}{c}{ Uraian } & Nilai \\
\hline 1. & Nilai terendah & 61 \\
2. & Nilai tertinggi & 95 \\
3. & Nilai rata-rata & 73 \\
4. & Persentase ketuntasan & $80 \%$ \\
\hline
\end{tabular}


Penerapan model pembelajaran $C R H$ berpengaruh cukup besar dalam meningkatkan keaktifan peserta didik di kelas. Hal ini dapat dilihat dari kenaikan jumlah peserta didik yang menyimak penjelasan guru, melaksanakan diskusi kelompok sesuai petunjuk guru, menyampaikan pendapat kepada guru atau sesama peserta didik, menulis dengan lengkap dan persentase ketuntasan. Diskusi yang berjalan dengan baik serta adanya tantangan agar masingmasing kelompok berlomba menulis jawaban yang benar di papan tulis.

Model pembelajaran $C R H$ dimulai dengan adanya penyampaian materi oleh peneliti. Pada saat peneliti menyampaikan materi, peserta didik menyimak dengan sungguh-sungguh dan mencatatnya di buku tulis. Selanjutnya adalah diskusi kelompok yang terdiri dari 5 peserta didik tiap kelompoknya. Dalam diskusi kelompok ini peserta didik saling menyampaikan pendapat ke sesama anggota kelompok.

Menurut pengamatan peneliti dan observer, peserta didik mengikuti kegiatan pembelajaran dengan gembira dan bersemangat terutama ketika kelompoknya menjawab soal dengan benar. Yang dilanjutkan dengan yel-yel dan bersorak horay.

Langkah-langkah model pembelajaran $C R H$ dapat dilaksanakan secara urut dan baik. Hal ini mampu meningkatkan keaktifan belajar dan hasil belajar peserta didik. Akan tetapi dalam pelaksanaan siklus 1 masih ada kendala yakni kegiatan kelompok yang kurang efektif. Anggota kelompok yang berjumah 5 orang ternyata berdampak pada masih adanya anggota kelompok yang tidak mengerjakan tugas. Bahkan ada beberapa peserta didik dalam kelompok yang lebih banyak menghabiskan waktunya untuk membicarakan hal-hal yang berkaitan dengan materi pelajaran. Oleh karena itu pada siklus 2 nanti peneliti akan membentuk kelompok dengan anggota sebanyak 4 orang. Dengan demikian diharapkan sluruh anggota kelompok dapat mengerjakan tugasnya dengan baik.

\subsection{Deskripsi Hasil Siklus 2}

Hasil pengamatan terhadap keaktifan belajar peserta didik dapat dirangkum pada Tabel 5 dan hasil belajar pada Tabel 6 .

Tabel 5. Keaktifan Belajar Siklus 2

\begin{tabular}{lllc}
\hline No. & \multicolumn{1}{c}{ Aspek Pengamatan } & Jumlah & Persentase \\
\hline 1. & Menyimak penjelasan guru & 27 orang & $90 \%$ \\
2. & Melaksanakan diskusi kelompok sesuai petunjuk guru & 27 orang & $90 \%$ \\
3. & Menyampaikan pendapat kepada guru atau sesama peserta didik & 23 orang & $77 \%$ \\
4. & Menulis dengan lengkap & 28 orang & $93 \%$ \\
5. & Bergembira dan bersemangat & 27 orang & $90 \%$ \\
\hline
\end{tabular}

Tabel 6. Hasil Belajar Siklus 2

\begin{tabular}{clc}
\hline No. & \multicolumn{1}{c}{ Uraian } & Nilai \\
\hline 1. & Nilai terendah & 63 \\
2. & Nilai tertinggi & 90 \\
3. & Nilai rata-rata & 72 \\
4. & Persentase ketuntasan & $83 \%$ \\
\hline
\end{tabular}

Tabel 5 dan Tabel 6 menunjukkan adanya peningkatan keaktifan dan hasil belajar peserta didik. Hal ini dapat terjadi karena model pembelajaran $C R H$ yang merupakan salah satu model pembelajaran kooperatif memang dirancang untuk meningkatkan keaktifan peserta didik 
melalui diskusi kelompok. Akibatnya pemahaman konsep peserta didik pada materi Lingkaran juga mengalami peningkatan. Hal ini sejalan dengan hasil penelitian Asih Suryani et al., (2016). Hasil penelitian menyatakan bahwa pembelajaran dengan $C R H$ dapat meningkatkan pemahaman matematis peserta didik pada materi penjumlahan dan pengurangan bilangan bulat secara signifikan.

Selain itu dengan adanya jumlah anggota kelompok sebanyak 4 orang menyebabkan masing-masing anggota kelompok dapat mengerjakan tugas dengan fokus yang baik. Tidak ada peserta didik yang melakukan kegiatan lain selain kegiatan diskusi kelompok. Berikut ini ditampilkan grafik yang merangkum keaktifan belajar dan hasil belajar peserta didik dari pra siklus, siklus 1 , dan siklus 2 .

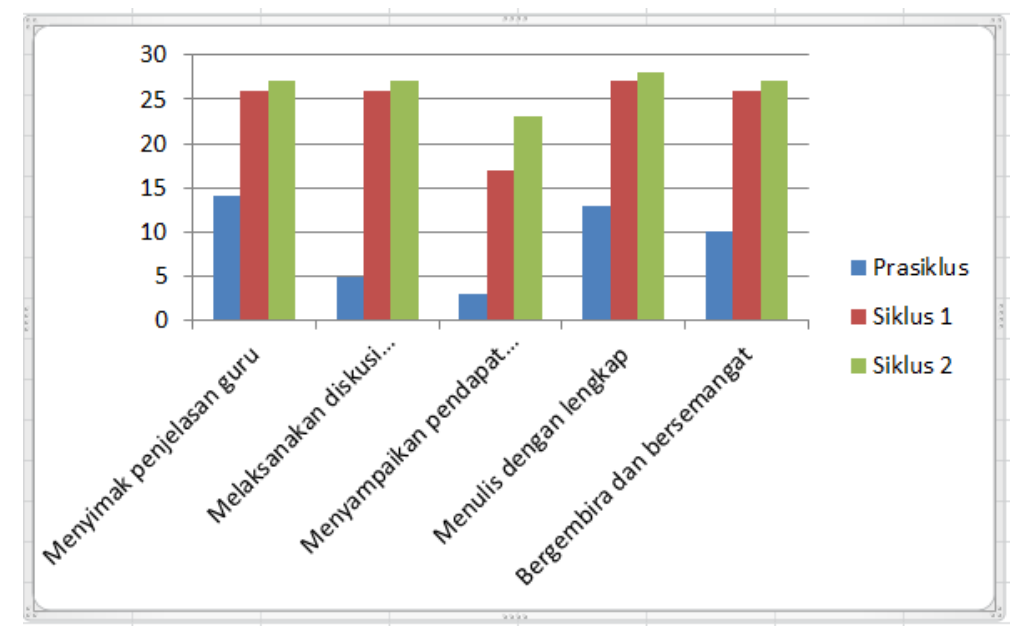

Gambar 2. Keaktifan Pra Siklus, Siklus 1, dan Siklus 2

Menurut Gambar 2 dapat dilihat bahwa semua indikator keaktifan belajar mengalami peningkatan yang cukup signifikan. Keaktifan yang rendah pada pra siklus dapat meningkat dikarenakan penerapan model pembelajaran $C R H$. Hasil ini sesuai dengan penelitian yang dilakukan oleh Jakse (2015: 174) menyatakan bahwa pelaksanaan kegiatan belajar mengajar dengan model pembelajaran kooperatif $C R H$ dapat meningkatkan minat, keaktifan dan hasil belajar. Penggunaan model pembelajaran $C R H$ ini sangat tepat untuk digunakan dalam proses pembelajaran, karena dapat menciptakan suasana kelas menjadi meriah, menyenangkan dan tidak membosankan sehingga dapat meningkatkan minat dan keaktifan peserta didik.

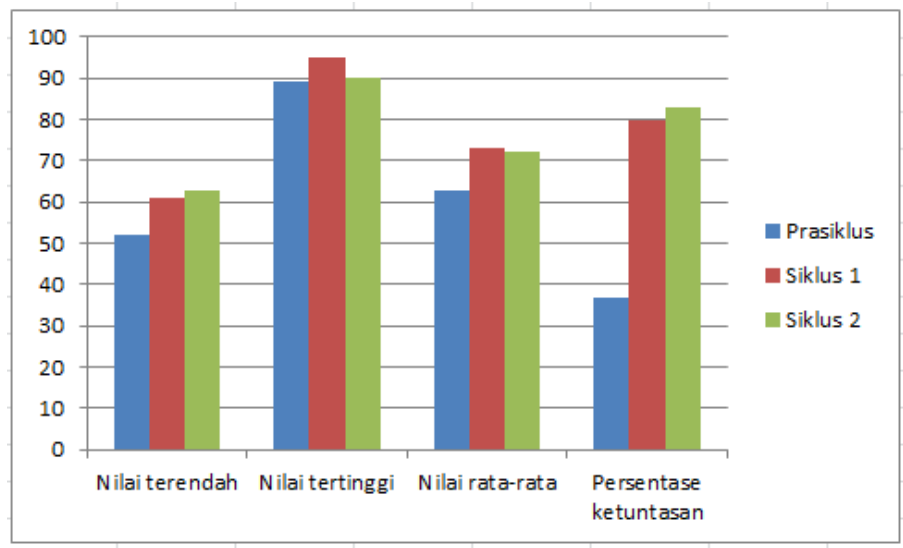

Gambar 3. Hasil Belajar Prasiklus, Siklus 1 dan Siklus 2 
Menyampaikan pendapat kepada guru atau sesama peserta didik merupakan salah satu indikator keaktifan belajar yang mengalami peningkatan tertinggi. Hal ini sesuai dengan hasil penelitian Arifatun Nahar et al., (2016) yaitu model pembelajaran Course Review Horay efektif terhadap kemampuan komunikasi matematis peserta didik. Menyampaikan pendapat kepada guru atau sesama peserta didik termasuk dalam kegiatan komunikasi matematis peserta didik.

Berdasarkan Gambar 3, ternyata hasil belajar meningkat dari prasiklus hingga siklus 2. Hal ini dapat dilihat bahwa banyak peserta didik yang nilainya melebihi KKM yang ditetapkan peneliti 68. Hasil ini sesuai dengan penelitian yang dilakukan oleh Pramadita et al., (2013:37) bahwa pembelajaran yang menggunakan model $C R H$ dapat mencapai ketuntasan belajar secara klasikal. Hal ini dikarenakan dalam pembelajaran dengan menggunakan model pembelajaran $C R H$ dapat membantu peserta didik lebih semangat dalam kegiatan pembelajaran. Peserta didik lebih tertarik untuk belajar karena model pembelajaran $C R H$ dapat membuat suasana kelas menjadi meriah. Sehingga dengan adanya pembelajaran yang seperti itu membuat peserta didik tidak mudah bosan dan mampu melatih perserta didik untuk terbiasa mengerjakan soal-soal latihan baik yang diberikan maupun yang tidak diberikan oleh guru.

\section{SIMPULAN}

Berdasarkan pembahasan dapat disimpulkan bahwa: (1) keaktifan belajar Lingkaran peserta didik kelas VIIIA SMP 4 Bae semester 2 tahun 2020 dapat ditingkatkan melalui model pembelajaran $C R H$, (2) hasil belajar Lingkaran peserta didik kelas VIIIA SMP 4 Bae semester 2 tahun 2020 dapat ditingkatkan melalui model pembelajaran $C R H$. Saran peneliti bagi pendidik hendaknya dapat menggunakan model pembelajaran $C R H$ untuk meningkatkan keaktifan belajar dan hasil belajar peserta didiknya. Keberhasilan penelitian ini memberi gambaran bahwa betapa pentingnya pembelajaran matematika dilakukan dengan menggunakan model yang dapat meningkatkan keaktifan belajar dan hasil belajar peserta didik.

\section{DAFTAR PUSTAKA}

Arifatun, Nahar., Dwi, Sulistyaningsih., \& Purnomo, Eko Andy. (2016). Keefektifan Model Pembelajaran Course Review Horay dengan Pendekatan Kontekstual terhadap Kemampuan Komunikasi Matematis pada Materi Segitiga Kelas VII. Jurnal Karya Pendidikan Matematika, 3(1), 48-59.

Asih, Suryani., Maulana, \& Julia. (2016). Pengaruh Pendekatan Course Review Horay (CRH) Terhadap Pemahaman Matematis Dan Motivasi Belajar Matematika Siswa Sekolah Dasar Pada Materi Penjumlahan Dan Pengurangan Bilangan Bulat. Jurnal Pena Ilmiah, 1(1), 110.

Fahmi, Royani., Hery, Sawiji., \& Patni Ninghardjanti. (2020). Pengaruh Keaktifan dan Fasilitas Belajar Terhadap Hasil Belajar Siswa Kelas XII SMK N 1 Banyudono 2019/2020. Jurnal Informasi dan Komunikasi Administrasi Perkantoran, 4(2), 112-122.

Fitrah, Amelia, \& Ferdinand Herman, Siahaan. (2015). Perbandingan Model Pembelajaran Kooperatif Tipe Course Review Horay dengan Time Token Arends Terhadap Hasil 
Belajar Matematika Siswa Kelas VIII di SMP Laksamana Batam Tahun Pelajaran 2014/2015. Pythagoras, 4(2), 69-76.

Ingti Binova, A. (2017). Upaya meningkatkan keaktifan siswa dalam pembelajaran matematika dengan permainan dakon di kelas II SDN Tambakromo 03 Pati (Skripsi tidak dipublikasikan). Fakultas Ilmu Pendidikan, Universitas Negeri Yogyakarta.

Jakse, H. S. (2015). Peningkatan Minat dan Keaktifan Belajar Matematika melalui Model Pembelajaran Kooperatif Course Review Horay. Jurnal Pendidikan Matematika, 14(2), 170-174.

Maslikhan. (2015). Peningkatan Hasil Belajar Matematika Materi Bangun Datar Sederhana Melalui Penggunaan Media Manipulatif Pada Siswa Kelas I-B MI Mamba’ul Ulum Bedanten Bungah Gresik (Skripsi tidak dipublikasikan). Universitas Islam Negeri Sunan Ampel Surabaya.

Miftahul, Huda. (2014). Model-Model Pengajaran dan Pembelajaran. Yogyakarta: Pustaka Pelajar.

Noor, Laila, Atini., \& Ali, Mahmudi. (2016). Keefektifan Cooperative Learning CRH dan NHT Ditinjau dari Sikap dan Prestasi Belajar Matematika Siswa. Pythagoras Jurnal Pendidikan Matematika, 16(2), 160-168.

Pramadita, A. A., Mashuri, \& R, Arifudin. (2013). Keefektifan Model Pembelajaran Course Review Horray terhadap Hasil Belajar dan Minat Belajar Siswa. Journal of Mathematics Education, 2(2), 34-39.

Ramlah., Dani, Firmansyah., \& Hamzah Zubair. (2014). Pengaruh Gaya Belajar dan Keaktifan Siswa terhadap Prestasi Belajar Matematika (Survey pada SMP Negeri di Kecamatan Klari Kabupaten Karawang). Jurnal Ilmiah Solusi, 1(3), 68-75.

Shoimin, Aris. (2014). 68 Model Pembelajaran Inovatif dalam Kurikulum 2013. Yogyakarta: Ar-Ruzz Media. 